\title{
THE INVOLVEMENT OF RELIGIOUS LEADERS IN CONFLICT RESOLUTION WITHIN TOLAKI PEOPLE OF KONAWE DISTRICT
}

\author{
Erens E. Koodoh \\ Gadjah Mada University \\ Email: koodoherens@gmail.com \\ Heddy Shri Ahimsa-Putra \\ Gadjah Mada University \\ Email: ahimsa putra@yahoo.com \\ Setiadi \\ Gadjah Mada University \\ Email: setiadi antro@ugm.ac.id
}

\begin{abstract}
This study aims to identify the various socio-cultural conditions of Tolaki people in Konawe that often engaging in inter-family conflict. The process of identifying the socio-cultural conditions leads to find the correlation between socio-cultural conditions and the types of inter-family conflicts and how they get resolved at the community level. Religious leaders are part of the efforts of solving the conflicts. In addition, this study is also aimed to determine and analyze the types of inter-family conflicts that exist and the processes for conflict resolution among families in the Tolaki in Konawe. The research data is based on two categories of informant; traditional leaders and ordinary informants that are public figures such as religious leaders, government officials within the scope of sub-district, village, and community members both at the level of individuals, families, and communities. The traditional leaders get involved in conflict resolution while public figures have experience on dealing with such conflicts and are sometime involved in a conflict. The work indicates that the conflicts in the Tolaki people take the form of closed and open conflicts. While the sources or the causes of the conflict come from tulura (speech), peowai (actions), and powaihako (behavior). The sources of the conflict then are manifested in the daily life of Tolaki people and become sisala'aineperapua (conflict in marriage), sisala'aine hapo-hapo (conflict by treasure), and conflict in social relations. Social and cultural conditions that often lead to inter-family conflicts are the difference in social strata, economic inequality, and religious differences. Tolaki People then settle their conflict through the expertise and charisma of religious and cultural leaders by the completion of melanggahako, mesokei, peohala, mombopoo'rai, sombalabu, and mosehe.
\end{abstract}

Keywords: Tolaki, religious, leader, inter-family, conflict, resolution. 


\section{INTRODUCTION}

There are two patterns of conflicts commonly found arising in the life of human beings namely vertical and horizontal conflicts. Vertical conflict is the conflict between communities and the government. The use of instruments of state violence, causing casualties among people is something commonly seen in such kind of conflict (Susan, 2009:99). While horizontal conflict is a conflict involving agencies at the community level or that occur among the people themselves. Horizontal conflicts can occur internally and externally as well. Internal conflict is normally involving agents contained in a community. Interpersonal conflict is targeted at the persons in the group and externally involving agents in a community with agents from other communities (Tomagola, 2006:41). Horizontal conflict in a society can arise for many reasons such as those based on inter-ethnic and inter-religious causes including what happened in Poso known as the Poso conflict (Li, 2010; Sangaji, 2010; Klinken, 2007; Hasrullah, 2009, Trijono, 2006; Karnavian dkk, 2008), conflict in Maluku (Klinken, 2007:147-148; Tumanggor, 2006:279) and conflict between Dayak and Madurese in West Kalimantan (Davidson, 2010:245-268; Prasojo, 2011). In addition, the social condition of a society often raises the trigger of a conflict (Maunati 2006:194-195; Suparlan 1993:37).

Conflicts between the members of society, both inter-ethnic conflicts, religious conflicts, internal conflicts within society or community, as well as other conflicts in any form will be the same also for the community causing loss of life, social relations, and possessions. The efforts of conflict resolution can be reached in many ways including negotiations such as what have been done in Poso and Maluku (Karnavian at.al, 2008:206; Hasrullah, 2009: ix; Waileruny, 2010:225). Tolaki people have recognized their various traditional mechanisms adopted to resolve conflicts in their lives. Conflict resolution in the Tolaki community closely related to one of their ways of life namely Tolaki inae kona sara iyee pine sara, inae lia sara iyee pinekasara. It means that someone who knows customs will be appreciated, but those who do not appreciate the indigenous values will be sanctioned. In addition, the community requires for moambongi (forgiveness) when a conflict occurs. The community would demand for monggolupe (forgetting) when the conflict is resolved.

The Tolaki is the tribe who inhabit the island of Sulawesi and Southeast peninsula known as the mainland of Southeast Sulawesi Province. Currently the Tolaki people inhabit five districts of the eleven districts/cities in the province. The work is based on research in the five districts in which the Tolaki people have walked together with other tribes such as Bugis, Makassar, Java, Bali, Lombok, Muna and Buton, who also came to the region persisting 
for several generations until today. In addition to ethnic diversity, there is also a diversity of religions in the region. Islam, Christianity, Catholicism, and Hinduism have coexisted since the times of their arrival. This paper highlights the lives of the Tolaki people as they have shown different from what happened in some locations experiencing conflicts between ethnic groups in the region. The Tolaki people, who also coexist with other tribes, have almost never experienced ethnic conflicts. The conflicts that often occur in their everyday life precisely occurred among their own fellow Tolaki people. The conflicts that have been found is in a form of a conflict that involves a family with another family members or conflicts within family members.

The work is supported by data that is obtained through very intensive observations and depth interviews with important key informants. The observation is conducted in the setting of direct experiences being in the situation of the phenomenon. In other words, it is based on a direct view of concrete events that occur in the society being studied (Hasan \& Koentjaraningrat, 1997:9; Bachtiar, 1997:112). Thus, this observation is an activity to gather as much information on the basis of what is visible on the targeted research (Bachtiar, 1997:114). While in-depth interview is aimed to collect information or data about human life, in this case the Tolaki community and convictions of those engaged in it (Koentjaraningrat, 1997:129).

\section{THEORIES OF CONFLICT AND THE TOLAKI PEOPLE}

Experts on the conflict studies have provided some definitions. For example mismatch belief, interest opposition, rivalry, disagreement and debate (Williams, 1970). It is also understood as a result of the interaction between the goals of two or more parties in a competitive situation (Oberschall, 1978), physical confrontation between parties (Webster as quoted by Pruitt \& Rubin 2009: 9), as a competition (Schmidt, 2001:2) and as an example of contention between the "indigenous" majority against the minority from outside (Chua, 1999). In this paper, the authors are much influenced by the theory of conflict proposed by Pruitt and Kim (2004:7-8) defining conflict as a perceived divergence of interest, a belief that the parties current aspiration are incompatible.

A wide variety of major conflicts often arose from a dispute that seems trivial, whether it is between individuals or between families (Ahimsa-Putra, 1999:142). The work focuses on conflicts that occur between families and refer to Pruitt and Kim (2004), Oberschall (1978), and Bartos and Wehr (2002) believing that conflict between families can be interpreted as differences of perception about the importance of a family with other families. It refers to 
the behavior that implies opposition or competition in the objectives of the parties that are mutually dependent. The family here is meant to be a social entity that is formed as a result of a marriage, often referred to as a household.

This work also uses a functional-structural paradigm where its origin can be found in the works of Auguste Comte (Poloma, 2010:23). This paradigm is sometimes called the theory of consensus with the argument that the rules of the culture of a community, or a structure may determine the behavior of its members, to channel their actions in ways that may be different to other communities (Jones, 2009:8-9). Besides Comte, structural functional theory proposed by Talcott Parsons also produces the most extensive elaboration of the structural and functional theory a major contributor to the earlier theory (Haryanto, 2012:19; Ritzer, 2012: 408-410). Emile Durkheim is also a thinker who contributed to the structural functional theory. According to Durkheim, a society in which there are various kinds of social institution is a social organism. These social institutions, as well as the body parts of a living organism, have their respective functions. The function of social institutions is conformity (correspondence) between these institutions with the needs of the social organism (Ahimsa-Putra, 2007:181).

In addition to Durkheim, one of the most important scientists in the field of anthropology is A.R. Radcliffe-Brown (Turner \& Maryanski, 2010: 63) adopting a functional method of structural Durkheim. Brown, in applying the concept of function as one of the main concepts in functional-structural paradigm, often makes the analogy between social life and organic life. Because of a certain perspective, social life has in common with the life of the organism. The function of this social institution is the correspondence between the institutions with the needs of the social organism. As disclosed by Brown: "Durkheim definition is that the 'function' of a social institution is the correspondence between it and the needs of the social organism. I would like to substitute for the term 'needs' the term 'necessary conditions of existence" (Brown, 1965:178). The concept of the needs of Durkheim, by Brown replaced by the conditions of existence (conditions of existence) that the conditions necessary for the existence or existence of something or the conditions required. For example Brown will see the essential conditions of social systems to reveal the continuity that is as the maintenance of rights and obligations between people so that interaction can take place (Turner dan Maryanski, 2010:74). The use of the concept means also for their acceptance of the notion that human society is also necessary existence of certain conditions, as well as in the world of animals or other living things (Ahimsa-Putra, 2007:182). In addition, it is important to mention here the concept of conflict resolution. 
Conflict resolution is any effort made to provide a solution to the controversy/ conflict, which can be accepted by all parties (Pruitt \& Rubin, 2009:311). Many ways of resolving conflicts or disputes in Indonesia, such as the war of words and mutual silence, compensation, bargaining through intermediaries, deliberation, and fighting ability (“war") (Ahimsa-Putra, 1999:159-164).

The Tolaki people view conflict as a dispute, misunderstanding of both intentional and unintentional that causes quarrels, fights until finally breaking of the rope silaturrahim or kinship, as well as the breakdown of communication between individuals with other individuals. Conflict in Tolaki People's perception is something that is highly undesirable to happen in their lives. But there is no denying that in the end, the conflict is a phenomenon that cannot be separated from public life in general and in particular the People Tolaki. The following will discuss several issues related to the conflict and more specifically in relation to inter-family conflicts such as type, shape, and a source of conflict in the People Tolaki in Konawe.

Tolaki people share some kind of conflict that often occurs in their lives namely (1) conflicts between man and nature, (2) conflicts between humans and the supernatural, and (3) conflicts between man and man. The types of conflicts emerge or transform in the form of covered or silent conflicts. No talk and interaction is found among those involved in the silent conflict. Those who are involved in the conflict will also avoid meeting both individually and in meetings involving many activities, for example in the wedding and other public gatherings. Beside silent, open conflict is also found within the Tolaki people. The open conflict is often openly manifested in the form of a fight and even murder cases.

\section{SOURCES OF CONFLICT WITHIN THE TOLAKI PEOPLE}

Some sources or causes of the conflict are found within the Tolaki people. They are identified in local language. The work provides the desciption of them with more detail explanation of Tulura (speech), Powaihako (behavior) and Peowai (acts). Tolaki people believe that one of the causes of conflict in daily life is because of a person's words and also how someone speaks the word. They call it Tulura (speech). Therefore, Tolaki People maintain ethics in speaking; to always pay attention to who is whom they speak with. For example, talking to an older person would not be the same as when talking with someone younger. In tulura or speech that may be the cause of this conflict, there are some specific things that are often a source of conflict in the People of Tolaki including Mowukuti or criticizing others, Mowinduki or defamatory, Mososangge or disgrace tell someone, Monduutulu or accused, 
and Mondomboka or convicted/accused.

Powaihako (behavior) that often leads to conflict is a behavior that does not comply with the rules and regulations, norms, and ethics in the life of man Tolaki. Powaihako actually a behavior or a behavior that does not directly harm another person, for example, throw spit in front of people or grumpy and say rude words in front of people without a clear purpose which direction the anger and harsh words were. Fraternal relations, kinship, may be disrupted or interrupted as a result of such behavior that is not in accordance with the general norms.

Peowai or acts that often cause conflicts are actions that are considered inappropriate because it does not correspond to the prevailing customary norms. The inappropriate actions include, for example, intentionally holding or touching another man's wife on inappropriate parts such as the breast or sexual organs. The misconduct example is an act that is not in accordance to the customary norms of decency and considered to trample on women's dignity, especially the family of her husband. Various sources of conflict between families that often occur in the lives of the Tolaki are also identified in this work. The conflict is usually originated from marital life which is derived from social relations and sometimes comes from possessions. The following are some important terminologies of marital based conflicts within the Tolaki people.

The Tolaki people recognize mombolasuako that means running/fleeing. This happens when a man and a woman agree to run or go from their homes to a place, for example to the house of a traditional leader (Tolea, pabitara, toono motuo, or pun'tobu), to the house of a government official (RT, RW, or village head), or to one of the families either side of the family. There are three reasons why elopement is commonly happening in the Tolaki community. First is molasu in which a man and a woman agreed to run away together because their parents do not approve their relationship. Second is pinolasuako where a man and a woman agreed to run for one of the parties, especially her parents disapproved of their relationship. And third is mepolasuako in which a woman invites a man to elope or a woman complained relation to the traditional leaders (toono motuo, Tolea, pabitara) or to the priest and asked them to keep her taken care to mate with a male. They also know momboko mendia or unwed pregnancy. Momboko mendia occurs when a man impregnates a girl and they are not in marriage so that conflict occurs within the two families.

The cause of conflict between other family originating from a marital problem is if there is a terako or being captured. This happens when a man, whether he is a young man or married, found being together with a woman in a deserted 
place and are doing something improper done by those who are not bound by a marital relationship. The Tolaki believe that this kind of act violates traditional norms of decency and gives a shame to the family. In addition, the Tolaki people also know umóapi (cheating). Umo'api can be interpreted as infidelity and is considered as one of the very serious conflict in the social life. Umoapi is one of the actions that is forbidden and considered a very despicable and embarrassing. They even believe that umo'api may not only cause a big conflict but also give a bad impact to the social life of the people such as natural disasters including floods, drought or prolonged rain or harvest failures.

The Tolaki also recognize property-based conflicts or sisala'a ine hapo-hapo. Conflicts between families due to the problem of property is more specialized to land inherited from their elders. In this case, there are several types of land ownership to be a source of conflict between families in the life of the Tolaki. Wuta tiari or land legacy is inherited from a common ancestor to his descendants. Wuta walaka is the land area of the former buffalo preservation. Walaka wuta is owned by a broad family originating from a common ancestor and in walaka that each of the family of a broad family originating from a common ancestor can release the buffalo. Waworaha which is the land of former residence of a family grove is characterized by the presence of plants or plant long-term and sago clumps on it. O'epe is the area where the growth of sago and ogalu or rice fields that belong to a large family of one cluster of common ancestors. In short, those all sources of conflict that can be the trigger for this land issue is land that formerly belonges to the family grove from a common ancestor that can be inherited.

\section{CONFLICT RESOLUTION AND LOCAL BELIEVE OF THE TOLAKI PEOPLE}

Several principles of resolving conflicts in the People Tolaki are identified. First is the principle of mbendeporombu or deliberation. Deliberation is a form of cooperative spirit which has always pursued and carried out by the traditional leaders, community leaders, including religious leaders, the elders in the community, and government. The elements that are always played an active role bring together the parties involved in the conflict along with his whole family. The second is Mbeokotu kombo, mbeohai (literally are siblings, children). It means that all people Tolaki brothers, whether it's siblings, a close relative, or brothers away. Therefore, the second principle is more emphasis on kinship or blood relationship or kinship. Below are some important findings from the Tolaki Community in dealing with conflict. 


\section{The Patterns of Conflict Resolution}

The process of conflict resolution in the People Tolaki inseparable from the role carried out by traditional leaders, community leaders, and local authorities. The pattern of conflict resolution performed by traditional leaders, community leaders, and the government in resolving the conflict in the Tolaki is a pattern pesoro mbondu or mediation, mbetulura or dialogue, metawari or negotiation, and mombesara as the last part in conflict resolution. But in the case of certain conflicts caused by umo'api (cheating) and mombetudari (oath), then the last part of the settlement of the conflict is mosehe. Those kinds of pattern have been done since the time of immemorial and are still implemented by the Tolaki people.

\section{Pesoro Ndulura (Mediation)}

Every conflict, then that becomes the first step in the process of conflict resolution in society Tolaki is the process in the form of mediation. Which is a mediator in the mediation process is puutobu, toono motuo, and Tolea / pabitara (referred to as traditional leaders), religious leaders, their elders in a society that is often referred to as community leaders, and government in terms of the RT, RW, Village head, and head. But the mediator, especially in the mediation process are the traditional leaders as they will facilitate communication of those two parties were involved in a conflict. The core of the mediation process undertaken by traditional leaders are asking the willingness of the parties involved to meet and dialogue to bring the parties to the conflict, the government, the elder, and presenting those who directly witnessed or know exactly sit the case of the causes of conflict (eg, to know the exact history of a piece of land that is a source of conflict).

\section{Mbetulura (Dialogue)}

The next stage should be done in the process of completion of the People Tolaki conflict is dialogue phase. Phase dialogue was conducted to determine what is really the main cause of the conflict or what underlies that dispute. In addition, the dialogue is also intended to seek a solution completion, open space of peace for the parties who are involved in the conflict, as well as the initial communication either by traditional leaders, community leaders, local authorities, and they are in conflict. With dialogue involving many parties, who cut off communication between the conflicting will reconnect. 


\section{Metawari (Negotiation)}

According to Fisher (2001:115) in the process of negotiating a settlement of conflict is the first step made by those who are in conflict when communication lines are completely cut off. According Tolaki, metawari or negotiation done to reopen the closed communication between those in conflict. Metawari process is actually to deliver custom stages that must be passed in the process of conflict resolution and what the obligation of one party against the other party. The most important thing in this metawari process is determining which side should fulfill its obligations and which side to accept it as the right stages, conditions, and obligations to be fulfilled by one party to the other later so that become a customary decision. The next step is a consultation to determine the final process of conflict resolution, which is called mombesara.

\section{Mombesara (Laying Down of Adat)}

The last stage in the pattern of conflict resolution in the Tolaki community is mombesara. It is conducted by Tolea/Pabitara with kalosara before pu'utobu (traditional leader), with the essence of the talks: the preface, containing the purpose and objective of the meeting; explaining in detail all the information and recognition of the offender, including evidence of his actions or the offense as well as his appeal to the customary meeting to be reconciled; describing in detail the particulars of the victim; an opinion or advice on alternative forms of punishment or fines imposed on the offenders deserve in accordance with the form of acts committed by the offenders. It is followed by comments, suggestions, and opinions of the puu'tobu (traditional leaders) and suggestions and opinions from toono motuo as the chairman of the customary village. Then suggestions and opinions of indigenous elders or those who are elder in the village are being heard. Requesting the demands from those representing the victim's family is also found here. Then it is followed by request and apology from those representing the perpetrator. Submission of conclusions by the puu'tobu to ratify the legal decisions is handed down to the perpetrators, including the claim that the decision is final, binding, and undeniable. It is also found in this stage the determination and execution of providing any liability that has been required in the process of metawari from the perpetrator to the victim, represented by Tolea. The word-the closing words of pabitara- also marked that the case has been completed and the custom event of mombesara also been completed. 


\section{Models of Conflict Resolution Based On Local Belief}

The Tolaki people only know their fines or restitution in the settlement of the conflict. Fines are applied in a provision that is standard according to customary of the Tolaki. Here are three different ways or mechanisms for resolving conflicts, particularly the conflicts among families, according to the custom of the Tolaki People in Konawe.

\section{Melanggahako}

The People of Tolaki recognizes what they call melanggahako. It is a way of conflict resolution having function to solve several types of conflicts including momboko mendia or pregnancy of an non-married woman. This occurs when a man impregnates a girl or a widow. In this melanggahako ritual, the man is obligated to pay a penalty to the woman's family. The first option is to pay powoka obiri consisting of two elements; goods and pohunggai worumata (one piece of sarong). The second option is to pay pohunggai sokibiri (one piece of sarong and pelanggahako (a piece of cloth). The last is the indigenous Taapombonaanaa a'koa consisting of two (2 eyes), namely two pieces of gloves and a buffalo. After the above conditions have been paid to the woman through mombesara, then the process continues with the administration of customary marriages under a normal marriage procession of the Tolaki community.

\section{Terako or Telangga Nirako (being caught)}

Terako or Telangga nirako is also called busted situations. This happens when a man and a woman, whether a girl or a widow staying together without anyone else, doing things that are not appropriate to religious and customary norms. The fines or compensation should be given by the deemed guilty in two cases. The first is powoka obiri consisting of two subjects, namely pohunggai worumata (1 sheet of cloth and gloves) and pohunggai sokibiri (1 sheet of cloth and gloves). The second is pelanggahako (1 piece of cloth) and indigenous Taapombonaanaa Akoa (2 pieces of gloves and one buffaloe/cow). The current situation the buffalo can be replaced by paying an appropriate sum of money. If all the fines mentioned above have been submitted through the customs or mombesara, then the process continues with customary marriages under normal marriage of the Tolaki tradition.

\section{Peohala}

Conflict resolution through this peohala will be executed if the community 
finds information from someone that a man and a woman having inappropriate intercourse outside of a marriage but the news was not true after being investigated. The person who spreads the news will later be penalized to pay for a fine. The application of penalties in this peohala differs according to the status of the contributing case. The application of the financial penalties is dependent on the case as well. If the maligned person is a girl (not married), then this is called peohala mohewu (mohewu = small). The penalty is by one piece: one piece of cloth/white gauze gloves or a single sheet. If the slandered person is a woman who has a husband, then this is called peohala owose (owose = large). The penalty is in the form of one (1) piece of kaci (white cloth) and a buffalo. If the slandered person is a girl who is being engaged, the sanctions fines equal to the peohala owose. For the mentioned types of peohala, the sanctions of defaming the fine is to be handed to the maligned through customs or mombesara.

\section{Mesokei}

The mesokei process of resolution is conducted when the community finds a case of a man and a woman who had a relationship of molasu (escaping from the community). Molasu means running away. The couple should get married immediately. This kind of marriage can occur because of three conditions. Molasu conditition is when the relationship is not approved by both parents of the men sides and the girl side. Pinolasuako occurs because a man and a girl agree to get together but the girl's parents did not approve their relationship while the parents of the man have agreed. Mepolasuako occurs because a girl invites a man to elope in the house of a priest, traditional leader, or a government official to get married. Mombolasuako is the opposite of mepolasuako where a man takes a girl in to the house of a priest, traditional leader, or government official to get married. The financial penalties imposed on the male are called rembinggare (two pieces of gloves), sokei aso kasu (one piece of cloth), peosawa'akoa (one buffalo/indigenous buffalo, pekopu (custom delivery of children to their parents) with one copy of female dress and one long linen sheet. After the fine is paid and delivered through mombesara, then the community continues with mesambepe which goes on to an agreement for the implementation of a marriage for those who are being caught.

\section{Somba Labu Or Popolo Soro}

The term of somba labu is actually equal to marriage and divorce. Somba labu or popolo soro happens usually caused by two conditions. First, it is when found 
a pregnant woman but her pregnancy is suspected to have an unidentified biological father. This happens because the woman has sex with more than one male (for many different causes). Intimate relationships by more than one female and one male can occur because of rape or other causes. Second, somba labu or popolo soro is implemented if found a pregnant woman but the families do not want the unification of the pregnant woman and her male partner in a marriage. It can occur because of differences in their belief background. Financial penalties are applied to men in somba labu or soro Popolo. The man should pay fine of melanggahako, consisting of one piece of linen, one buffalo/ custom buffalo, two pieces of gloves, a pack of chalk series, areca and tobacco, wrapped in one copy of glove. The other penalty is for the man to pay for all the requirements of a normal marriage. Another option is mobinda, to pay a fine of one piece of fabricate linen and one buffalo. The last is to pay a penalty in the form of fees for waiting for the baby's birth and his living expenses for two years. Fees and living cost for waiting the birth of a child during the two years is tentative and depends on the outcome of deliberations. Mobinda process or mowea (divorce) can be done at the time of the payment of fines and can also be done three months after the woman giving birth to her baby. It depends on the outcome of deliberations both sides.

\section{Mombopo O'rai}

Mombopo o'rai happens if the community finds a husband and his wife to decide to divorce. Financial penalties are applied to people asking for a divorce. The penalty is equal to both the husband and the wife. The penalty fee is one piece of linen cloth and one buffalo (indigenous buffalo).

\section{Mosehe}

Literally, mosehe an amalgamation of two words seheand mo. Mo means to do something, and sehe which means holy or health. Mosehe means selfpurification efforts of all wrongdoing. Or in other words, mosehe is liberating people from various disorders and problems that make people depressed, threatened, and which cause discomfort. Mosehe on the Tolaki consists of five kinds: mosehe ndiolu (purification ceremonies themselves by using an egg as a victim), mosehe manu (purification ceremonies themselves by wearing a chicken as its victims), mosehe dahu (purification ceremonies themselves by wearing a dog as its victims), mosehe ngginiku (purification ceremonies themselves by wearing buffalo as its victims), and mosehe ndoono (purification ceremonies themselves by using its human cost) (Tarimana, 1988: 236). At the 
present time, mosehe dahu (purification ceremonies themselves by wearing a dog as its victims) and mosehe ndoono (purification ceremonies themselves using humans as its victims) no longer practiced. It began after the arrival of Islam in the Tolaki and therefore deemed to be inconsistent with religious norms.

There are two kinds of Mosehe functions including the function of resolving conflicts that occur between men both individuals and between families and the function of as purification of domestic/village if there is a variety of things that bring misery to humans such as disease outbreaks, natural disasters, or failure prolonged harvest. Mosehe in the Tolaki community is to apply when there is umo'api or infidelity.

\section{CONCLUSION}

Socio-cultural background is very important to understand the conflict within the Tolaki community. The study shows that the conflict between families that frequently occurs is triggered by differences in social class, level of economic life, and religious differences. Indeed, the social classes have now experienced a shift in meaning, especially to the traditional societies with social class system. In the past, The Tolaki people recognize this social class in the forms of royal and non-royal. However, this classification often appears to be raised again in case of a conflict involving either among individuals or families. In the context of the individual relations (relationship of men and women), people count on social structures that sometimes triggers a conflict. Similarly, with to doing marriage, someone usually questions others of their social status. Religious leaders would have an important role here as the important elements in the society with better social status.

The conflict resolution mechanisms within the Tolaki, such as Melanggahako, Peohala, Mesokei, Somba Labu or Popolo Soro, Mombopo O'rai and Mosehe, show that all things pertain to the settlement of the conflict within the framework of maintaining the ties of kinship between people. In any case, the Tolaki believe that they have ties of kinship and blood ties that can be traced through the family tree (kuku'aha) inherited and transformed from generation to generation. In this process people need someone who are highly respected due to their capacity and status. Religious leaders play a significant role here as the knowledgeable person who get people's trust.

Customary law, which is believed to be the important public norm within the Tolaki community, actually has an element of force, in the sense that the community should be subject to the customary rules. It is in place to maintain 
the harmony of life. Therefore, provisions which are governed by and through customs should not be violated. The rule breakers will be punished socially and with the punishment of sangia (God in old Tolaki tradition. The belief now has changed, the Tolaki believe in Allah SWT since the hold Islam as their religion). The phrases of inae kona sara iyee pine sara, inae lia sara iyee pinekasara is derived from the value of kalosara that is still very effective in resolving conflicts between families. A person or a family who will not be reconciled through the media of kalosara means the person or the family is the person or family who mate sara deserving social condemnation and punishment from Allah, the Almighty. Another important point that should be noted is that although the Tolaki are sometimes in conflict, they are very easily reconciled. In many cases of conflict, the Kalosara is still regarded as a symbol to unite all parties. The sacred values of the kalosara is highly respected and regarded as a source of values that can solve all the problems within the Tolaki society. Through the media of kalosara, all things associated with the error, no matter how it is, is inexcusable. Tolaki people who make mistakes can be rehabilitated through the mechanism of settlement of indigenous Tolaki systems.

\section{BIBLIOGRAPHY}

Ahimsa-Putra. S. H. (1999). Cara-cara Menyelesaikan Sengketa dalam Masyarakat Pedesaan di Indonesia. Unisia. Vol. 20. Numbor 4. Page: 141173.

Bachtiar. W. H. (1997). Pengamatan Sebagai Suatu Metode Penelitian. in Metode-Metode Penelitian Masyarakat, ( $3^{\text {rd }}$ edition). Koentjaraningrat (Ed). Jakarta. PT. Gramedia Pustaka Utama

Bartos. J. O \& Wehr, P. (2002). Using Conflict Theory. Cambridge UK: Cambridge University Press.

Brown. R. A. R. (1965). Structure and Function in Primitive Society, Essays and Addresses. New York. The Free Press.

Chua. L. A. (1999). Markets, Democracy, and Ethnic Conflict. in Proceedings of the Annual Meeting (American Society of International Law). 93: 1-5.

Davidson. S. J. (2007). Culture and Rights in Ethnic Violence. in The Revival of Tradition in Indonesian Politics: The Deployment of Adat from Colonialism to Indiginism. Jamie S. Davidson, David Henley (Eds). New York: Routledge 
Fisher. S., Dekha, I. A., Richard, S., Jawed, L., Steve, W., \& Sue, W. (2001). Mengelola Konflik: Ketrampilan dan Strategi untuk Bertindak. Jakarta. SMK Grafika Desa Putra

Haryanto. S. (2012). Spektrum Teori Sosial, Dari Klasik Hingga Postmodern. Yogyakarta. Ar-Ruzz Media.

Hassan. F. \& Koentjaraningrat. (1997). Beberapa Azas Metodologi Ilmiah. in Metode-Metode Penelitian Masyarakat. ( $3^{\text {rd }}$ edition). Koentjaraningrat (Ed). Jakarta. PT. Gramedia Pustaka Utama

Hasrullah, (2009). Dendam Konflik Poso (Periode 1998 - 2001), Konflik Poso dari Perspektif Komunikasi Politik. Jakarta. PT. Gramedia Pustaka Utama

Jones. P. (2009). Pengantar Teori-Teori Sosial, Dari Teori Fungsionalisme Hingga Post-Modernisme. Alih Bahasa : Achmad Fedyani Saifuddin. Jakarta. Yayasan Obor Indonesia

Karnavian. M. T., Idham, A., Herry, R. N., Reza, A. D., Samuel T. T., Iver S. M, Surato, S. W. (2008). Indonesian Top Secret, Membongkar Konflik Poso. Jakarta, PT. Gramedia Pustaka Utama

Koentjaraningrat. (1997). Metode Wawancara. in Metode-Metode Penelitian Masyarakat. Koentjaraningrat (Ed). Jakarta: PT. Gramedia Pustaka Utama

Li. T. M. (2007). Adat in Central Sulawesi :Contemporary Deployments. in The Revival of Tradition in Indonesian Politics: The Deployment of Adat from Colonialism to Indiginism. Jamie S. Davidson \& David Henley (Eds). New York. Routledge

Maunati. Y. (2006). Identitas Dayak, Komodifikasi dan Politik Kebudayaan, Yogyakarta. LkiS Pelangi Aksara

Oberschall. A. (1978). Theories of Social Conflict. in .Annual Review of Sociology. 4: 291-315.

Poloma. M. M. (2010). Sosiologi Kontemporer. Jakarta: PT. RajaGrafindo Persada.

Prasojo, Z. H. (2011). Indigenous Community Identity Within Muslim Societies in Indonesia: A Study of Katab Kebahan Dayak in West Borneo. in Oxford Journal of Islamic Studies. Vol. 22. No. 1. hal: 50-65.

Pruitt. G. D. \& Jeffrey, Z. R. (2009). Teori Konflik Sosial. Soetjipto, H.P. \& Soetjipto, S.M. Yogyakarta: Pustaka Pelajar.

Pruitt. G. Dean. \& Sung H. K. (2004). Social Conflict: Escalation, Stalemate, and Settlement. Third Edition. New York. McGraw-Hill. 
Ritzer. G. (2012). Teori Sosiologi Dari Sosiologi Klasik Sampai Perkembangan terakhir Postmodern. Yogyakarta: Pustaka Pelajar.

Sangaji. A. (2007). The Masyarakat Adat Movement in Indonesia: A Critical Insider's View. in The Revival of Tradition in Indonesian Politics: The Deployment of Adat from Colonialism to Indiginism. Davidson, J.S \& Henley, D. (Eds). New York: Routledge.

Schruder. W. I. \& Bettina E. S. (2001). Violent Imaginaries and Violent Practices. in Anthropology of Violence and Conflict. Bettina E. S. \& Schruder, W.I. (Eds). London and New York: Routledge.

Suparlan.P. (1993). Masyarakat Sakai di Riau. In Masyarakat Terasing di Indonesia. Koentjaraningrat (ed). Jakarta: PT. Gramedia Pustaka Utama

Susan. N. (2012). Negara Gagal Mengelola Konflik, Demokrasi dan Tata Kelola Konflik di Indonesia. Yogyakarta. Kerjasama KoPi dan Pustaka Pelajar

-------, (2010). Pengantar Sosiologi Konflik dan Isu-Isu Konflik Kontemporer. Yogyakarta: Kencana

Tomagola. A. T. (2006). Republik Kapling. Yogyakarta: Resist Book.

Trijono. L. (2006). Konflik dan Prospek Perdamaian di Poso. in Fenomena Konflik Sosial di Indonesia: dari Aceh sampai Papua. Koeswinarno \& Abdurahman, D. (Ed). Yogyakarta: Lembaga Penelitian UIN Sunan Kalijaga

Tumanggor. R. (2006). Pemetaan Konflik di Maluku: Ambon. in Fenomena Konflik Sosial di Indonesia: dari Aceh sampai Papua. Koeswinarno \& Abdurahman, D. (Ed). Yogyakarta: Lembaga Penelitian UIN Sunan Kalijaga

Turner. H. J. \& Alexandra, M. (2010). Fungsionalisme. Yogyakarta: Pustaka Pelajar.

Van Klinken. G. (2007). Communal Violence and Democratization in Indonesia: Small Town Wars. New York: Rotledge.

Waileruny, S. (2010). Membongkar Konspirasi di Balik konflik Maluku. Jakarta. Yayasan Pustaka Obor Indonesia.

Williams, Jr. R. M. (1970). Social Order and Social Conflict. in :Proceedings of the American Philosophical Society. 114. (3): 217-225. 